ББК 67.402

\title{
СУДЕБНАЯ ПРАКТИКА ПО КЛАССИФИКАЦИИ ТОВАРОВ В СООТВЕТСТВИИ С ЕДИНОЙ ТОВАРНОЙ НОМЕНКЛАТУРОЙ ВНЕШНЕЭКОНОМИЧЕСКОЙ ДЕЯТЕЛЬНОСТИ ЕВРАЗИЙСКОГО ЭКОНОМИЧЕСКОГО СОЮЗА
}

\author{
(c) 2021 Небеснюк Светлана Александровна \\ аспирант кафедры финансового, банковского и таможенного права \\ имени профессора Нины Ивановны Химичевой \\ Саратовская государственная юридическая академия, Россия, Саратов \\ E-mail: nebesnyuksvetlana@yandex.ru
}

В статье рассматриваются правовые позиции Верховного суда Российской Федерации по классификации товаров в соответствии с единой Товарной номенклатурой внешнеэкономической деятельности Евразийского экономического союза в 2017-2020 гг. с целью выявления факторов, обуславливающих неправильное применение правовых норм в данной сфере таможенными органами.

Ключевые слова: классификация товаров, ТН ВЭД ЕАЭС, судебная практика, правовая позиция Верховного суда РФ, оспаривание решений таможенных органов.

Интерес к проблемам классификации товаров для таможенных целей обусловлен в первую очередь тем, что величина подлежащих уплате (взиманию) таможенных платежей находится в прямой зависимости от классификационного кода товара согласно единой Товарной номенклатуре внешнеэкономической деятельности Евразийского экономического союза (далее - ТН ВЭД). Нередко код товара приобретает спорный характер, поскольку финансовая деятельность таможенных органов направлена на пополнение доходной части федерального бюджета, а хозяйствующие субъекты заинтересованы в минимизации своих расходов на уплату таможенных платежей [1, с. 47]. Такие споры разрешаются в административном либо судебном порядке.

Статистика свидетельствует о том, что судебные акты по итогам рассмотрения дел о классификации товаров в соответствии с ТН ВЭД далеко не всегда принимаются в пользу таможенных органов, участники внешнеэкономической деятельности (далее - участники ВЭД) успешно отстаивают свою позицию в суде. Так, в 2020 г. из 933 рассмотренных дел данной категории в пользу таможни принято 49\% решений, а в пользу хозяйствующих субъектов - 41\%; в 2019 г. количество рассмотренных дел составило 959, из них в пользу таможенных органов принято 48\% решений, а в пользу участников ВЭД - 39\%; в 2018 г. данное соотношение было прямо противоположным - из 1088 рассмотренных дел в пользу таможни принят 41\% решений, а в пользу участников ВЭД - 49\% (по остальной части дел хозяйствующие субъекты отказались от поданных заявлений); в 2017 г. из 803 рассмотренных дел в пользу таможни принято 50,7\% решений [2].

Исходя из изложенного, очевидной представляется необходимость систематического анализа судебной практики в данной сфере для выявления факторов, обуславливающих неправильное применение правовых норм, регулирующих классификацию товаров в соответствии с ТН ВЭД.

К числу судебных споров, основаниями которых выступают обстоятельства классификации товаров, относят дела об оспаривании непосредственно решений (либо предварительных решений) о классификации (по ним приведена статистика за 2017-2020 гг.), а также дела, в рамках которых заявители оспаривают требования таможенных органов об уплате таможенных платежей, решения об отказе в выпуске товаров, о внесении/ отказе во внесении изменений (дополнений) в сведения, заявленные в декларации на товары, а также решения таможенных органов о привлечении к административной ответственности за недекларирование либо недостоверное декларирование товаров [3].

Категория дел об оспаривании решений о классификации содержит в своей основе несогласие декларантов с действиями таможенных органов, которые принимают решение об изменении заявленного лицом кода товара с целью 
доначисления таможенных платежей [1, с. 47]. В предмет доказывания по данной категории дел входит установление признаков (свойств, характеристик) декларируемого товара, имеющих значение для его правильной классификации в соответствии с ТН ВЭД [4]. Дело в том, что выбор конкретного кода ТН ВЭД всегда основан на оценке классификационных признаков товара, подлежащих описанию, а процесс описания связан с полнотой и достоверностью сведений о товаре [5].

Случаи неправильного определения таможенными органами классификационных признаков товара выявляются, как правило, в процессе судебного разбирательства. К примеру, в определении от 19 марта 2020 г. Верховный суд РФ поддержал позицию участника ВЭД по классификации бракованной части ввезенного товара - инкубационных куриных бройлерных яиц (неоплодотворенных) в субпозиции ТН ВЭД 0407 110000 («оплодотворенные яйца для инкубации: кур домашних (Gallus domesticus)»). Исходя из пояснений [6] к данной товарной субпозиции, суд установил, что для правильной классификации товара имеет значение только предполагаемое использование ввозимых куриных яиц - их предназначение для инкубации, а не само по себе обстоятельство, что часть ввезенных яиц оказалась непригодной для инкубации (неоплодотворенной), на чем настаивал таможенный орган. Согласно внешнеторговым контрактам, разрешениям Россельхознадзора на ввоз товара, ветеринарным свидетельствам на утилизацию и накладным, представленным таможенному органу при декларировании, бракованная часть товара ввозилась исключительно с целью выращивания цыплят-бройлеров и в последующем была утилизирована [7].

Следует учитывать, что правовое значение для классификации товара имеют критерии разграничения по товарным позициям ТН ВЭД с учетом Основных правил интерпретации ТН ВЭД (далее - ОПИ ТН ВЭД). Принимая решение об отнесении товара к конкретной товарной позиции (субпозиции), классификационный признак (критерий разграничения) определяется исходя из наименований и (или) текстов товарных позиций (субпозиций) ТН ВЭД, соответствующих примечаний и пояснений к ним $[5,6]$, немотивированное отклонение от которых недопустимо [8]. При этом не исключены примеры ошибочного применения ОПИ ТН ВЭД и (или) толкования таможенными органами наименований классификационных группировок и пояснений к ним.

В данной связи вызывает интерес мотивировка позиции Верховного суда РФ по классификации «кузова для полуприцепа» по коду ТН ВЭД 871690300 0, сформулированная в определении от 27 декабря 2017 г. Проведенный анализ текста товарной позиции ТН ВЭД 8716 («Прицепы и полуприцепы; прочие несамоходные транспортные средства; их части») и пояснений к ней, а также пояснений к товарной позиции ТН ВЭД 7309, применимой, mutatis mutandis, к позиции ТН ВЭД 7611 («Резервуары, цистерны, баки и аналогичные алюминиевые емкости для любых веществ ...»), позволил суду сделать вывод о том, что контекст товарной позиции 7611 ТН ВЭД предполагает отнесение к ней емкостей (цистерн), по своему функциональному назначению предназначенных для стационарного хранения соответствующих жидкостей [6]. Тогда как ввезенные товары предназначены для перемещения нефтепродуктов, их стационарное использование не предполагается конструкцией. Товары, исходя из описания, конструкционных особенностей, принципа работы и функционального назначения, представляют собой часть транспортных средств - безрамных полуприцепов-цистерн. Из текста товарной позиции 8716 ТН ВЭД следует, что к ней относятся как транспортные средства, в том числе полуприцепы, так и их части. В свою очередь таможенный орган при принятии решения о классификации данных товаров исходил из их наименования, не приняв во внимание указанные пояснения к ТН ВЭД, свойства и характеристики ввозимых товаров [9].

Проверяя обоснованность вынесенного таможенным органом классификационного решения, суды руководствуются принятыми в соответствии с ОПИ ТН ВЭД решениями (разъяснениями) ФТС России и Евразийской экономической комиссии (далее - ЕЭК) по классификации отдельных видов товаров [4].

В связи с этим важным представляется вывод Верховного суда РФ, сделанный в определении от 17 июня 2020 г., согласно которому участник ВЭД, декларируя товар при его ввозе по коду ТН ВЭД 9619008109 («Детские пеленки и подгузники и аналогичные санитарно-гигиенические изделия: детские пеленки и подгузники из прочих материалов», ставка НДС - 18\%), вправе в 
течение трех лет с момента уплаты таможенных платежей инициировать процедуру возврата излишне уплаченных сумм, если подтвердит наличие у ввезенного товара тех свойств, которые, согласно сложившимся в правоприменительной практике подходам, позволяли ставить вопрос о классификации этого товара по коду подсубпозиции ТН ВЭД 9619008101 («Детские пеленки и подгузники из бумажной массы, бумаги, целлюлозной ваты или полотна из волокон целлюлозы», ставка НДС - 0\%). Данный вывод суда основан на том, что налог уплачен и товар выпущен для внутреннего потребления до принятия и вступления в силу (16 декабря 2017 г.) решения ЕЭК от 14 ноября 2017 г. № 156 «О внесении изменений в решение ЕЭК от 16 сентября 2014 г. № 156 («О классификации подгузников детских одноразовых по ТН ВЭД ЕАЭС»)». Таким образом, изменения от 14 ноября 2017 г., допускающие согласно ОПИ ТН ВЭД 1, 3 (в) и 6 возможность только одного варианта классификации одноразовых детских подгузников, абсорбирующий слой которых изготовлен из нескольких материалов, по наиболее высокому в порядке возрастания коду в рамках товарной позиции ТН ВЭД 9619 00 (в подсубпозиции 961900810 9), применению не подлежат. Судом также учтено, что участник ВЭД действовал добросовестно в соответствии с ранее существовавшей практикой классификации товаров, в том числе международной, имеющей устойчивый характер [10, 11].

В случае неоднозначности возможных вариантов классификации товара и отсутствия принятого решения по классификации на уровне Евразийского экономического союза таможенным органам следует принимать во внимание классификационные решения и прочие рекомендации (разъяснения) Всемирной таможенной организации, немотивированный отказ от учета которых не допускается. В противном случае на таможенный орган возлагается обязанность по доказыванию неотносимости такого решения (рекомендации, разъяснения) к задекларированным товарам [4, 12].

Кроме того, при разрешении споров о классификации товаров суды принимают во внимание международную практику отнесения товара к соответствующему коду ГС, в том числе классификационные решения других стран-участниц ГС и международных организаций, содержащие аргументацию классификации. Такая практика обусловлена стремлением к исключению си- туаций, когда декларируемый товар в стране отправления и в Российской Федерации классифицируется по различным кодам ГС [4, 7, 9]. К сожалению, международная практика классификации не всегда учитывается таможенными органами при принятии классификационных решений.

В определении от 27 декабря 2017 г. Верховный Суд РФ, поддержал позицию участника ВЭД, указав на недопустимость оставления без внимания его довода о наличии международной практики по классификации аналогичных товаров в странах, использующих ГС (база данных классификационных решений Европейского союза), поскольку различие в классификации одного и того же товара в странах экспорта и импорта указывает на возможность произвольной классификации и нарушения принципа равенства участников ВЭД [9].

Предмет доказывания по данной категории дел обуславливает необходимость проведения экспертиз в целях определения классификационного признака товара (материала изготовления, состава, назначения, конструкции, иных технических и функциональных характеристик) и привлечения специалистов для оказания консультативной помощи.

Так, Верховный Суд РФ, отказывая таможенному органу в пересмотре принятых судебных актов по ряду дел о классификации обуви (заявленный код ТН ВЭД 640510000 9), исходил из результатов судебной экспертизы, установившей, что материал, из которого изготовлен верх обуви - композиционная кожа, натуральное происхождение такого материала исключено (классификационный признак). Основанием для назначения судебной экспертизы послужили диаметрально противоположные выводы таможенного эксперта и эксперта торговопромышленной палаты [13].

Неправильная классификация товара таможенным органом может быть обусловлена неграмотной постановкой вопросов перед таможенным экспертом [14, с. 21] либо его ошибочными выводами об идентификации товара и его классификационных признаках. Так, например, Верховный суд РФ в определении от 07 октября 2019 г. и нижестоящие суды поддержали позицию участника ВЭД о классификации моющих установок по коду ТН ВЭД 842430010 0. Оценив выводы экспертов и консультации специалистов, суд отметил, что заключение таможенного 
эксперта содержит противоречивый вывод об относимости товара к «механическим устройствам для мойки автомобилей» (код ТН ВЭД 8424 89000 1), при этом согласуется с актом экспертизы, представленным участником ВЭД, по вопросу о принципе работы моющих установок (один из классификационных признаков товара) [15].

Кроме того, неправильное применение таможенными органами правовых норм, регулирующих классификацию товаров в соответствии с ТН ВЭД, может быть обусловлено объективными факторами: отсутствием полных (достоверных) сведений о наименовании, характеристиках товара и иной информации, необходимой для классификации, по причине не указания декларантом либо непредставления им (представления в неполном объеме) документов, подтверждающих классификационные признаки товара, и иными. Не смотря на это, таможенным органам необходимо придерживаться практики неопровержимого документального подтверждения классификационных признаков товара, на которых основано решение (либо предварительное решение) о классификации (в том числе посредством таможенной экспертизы).

Подводя итоги, следует отметить, что таможенным органам в целях единообразного правоприменения и недопущения нарушений прав и законных интересов участников ВЭД необходимо обеспечить систематическое проведение анализа судебной практики по классификации товаров в соответствии с ТН ВЭД и регулярное повышение квалификации своих сотрудников.

\section{Библиографический список}

1. Бакаева О.Ю., Цидилина И. А. Судебная практика по осуществлению таможенными органами администрирования таможенных платежей // Вопросы экономики и права. 2015. № 2. С. 47-52.

2. Ежегодный сборник «Таможенная служба Российской Федерации» в 2017 г., 2018 г., 2019 г., 2020 г. URL: https://customs.gov.ru/activity/results/ezhegodnyj-sbornik-tamozhennaya-sluzhba-rossijskoj-federaczii (дата обращения: 12.04.2021).

3. Александрова Е.Н. Судебная практика по спорам о классификации товаров в соответствии с единой Товарной номенклатурой внешнеэкономической деятельности Евразийского экономического союза // Информационно-аналитический журнал «Арбитражные споры». 2019. № 3. С. 5-28. Доступ из справ.-правовой системы «Консультант Плюс».

4. Постановление Пленума Верховного Суда РФ от 26 нояб. 2019 г. № 49 «О некоторых вопросах, возникающих в судебной практике в связи с вступлением в силу Таможенного кодекса Евразийского экономического союза». Доступ из справ.-правовой системы «Консультант Плюс».

5. Определение Верховного Суда РФ от 08 июня 2020 г. № 309-ЭС20-7842 по делу № A60-8913/2019. URL: https://vsrf.ru/stor_pdf_ec.php?id=1891530 (дата обращения: 20.04.2021).

6. Рекомендация Коллегии ЕЭК от 07 нояб. 2017 г. № 21 «О Пояснениях к единой Товарной номенклатуре внешнеэкономической деятельности Евразийского экономического союза».URL: http://www.eurasiancommission. org/ru/act/trade/catr/psn/Pages/default.aspx (дата обращения: 12.04.2021).

7. Определение Верховного Суда РФ от 19 марта 2020 г. № 310-ЭС19-24856 по делу № A09-12191/2018. URL: https://vsrf.ru/stor_pdf_ec.php?id=1872136 (дата обращения: 20.04.2021).

8. Решение Суда Евразийского экономического сообщества от 20 мая 2014 г. по делу № 2-4/7-2014. Доступ из справ.-правовой системы «Консультант Плюс».

9. Определение Верховного Суда РФ от 27 дек. 2017 г. № 305-КГ17-13486 по делу № A40-163774/2016. URL: https://vsrf.ru/stor_pdf_ec.php?id=1610000 (дата обращения: 19.04.2021).

10. Определение Верховного Суда РФ от 17 июня 2020 г. № 303-ЭС20-816 по делу № A51-24425/2018. URL: https://vsrf.ru/stor_pdf_ec.php?id=1895052 (дата обращения: 20.04.2021); Решение Арбитражного суда Приморского края от 19 нояб. 2020 г. по делу № A51-24425/2018. URL: https://kad.arbitr.ru/Card/098220d3-4169407a-8de1-028ebb3a600a (дата обращения: 20.04.2021).

11. Определение Верховного Суда РФ от 25 дек. 2017 г. № 305-КГ17-12541 по делу № А40-126986/2016. Доступ из справ.-правовой системы «Консультант Плюс».

12. Определение Верховного Суда РФ от 20 сен. 2017 г. № 305-КГ17-3138 по делу № A40-32818/2016. URL: https://vsrf.ru/stor_pdf_ec.php?id=1579086 (дата обращения: 19.04.2021). 
13. Определение Верховного Суда РФ от 23 сент. 2020 г. № 303-ЭС20-12374 по делу № А51-7449/2017. Доступ из справ.-правовой системы «Консультант Плюс»; Определение Верховного Суда РФ от 17 сент. 2020 г. № 303-ЭС20-11789 по делу № A51-15460/2017. URL: https:/vsrf.ru/stor_pdf_ec.php?id=1913418 (дата обращения: 21.04.2021); Определение Верховного Суда РФ от 22 апр. 2020 г. № 303-ЭС20-5782 по делу № А5115671/2017. URL: https://vsrf.ru/stor_pdf_ec.php?id=1881264 (дата обращения: 21.04.2021); и др.

14. Воробьев И.И. Экспертное обеспечение таможенных органов: состояние и проблемы // Таможенная политика России на Дальнем Востоке. 2019. № 3(88). С. 18-24.

15. Определение Верховного Суда РФ от 07 окт. 2019 г. № 307-ЭС19-16493 по делу № A56-117915/2018. URL: https://vsrf.ru/stor_pdf_ec.php?id=1818352 (дата обращения: 20.04.2021); Постановление Арбитражного суда Северо-Западного округа от 06 июня 2019 г. по делу № A56-117915/2018. URL: https://kad.arbitr.ru/ Card/856c9ae3-edbc-4fe7-b260-937cf349f325 (дата обращения: 20.04.2021). 